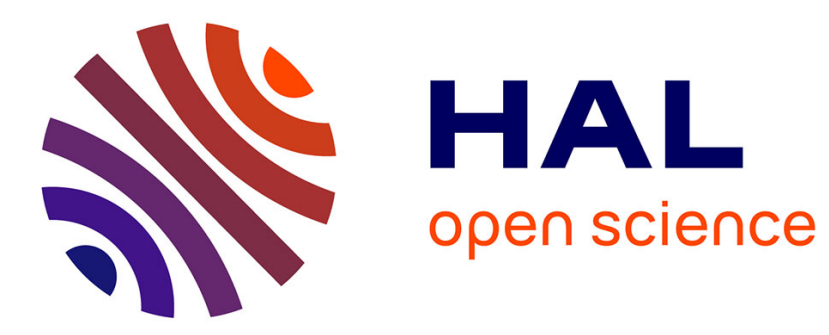

\title{
Homonymy, Polysemy, and Synonymy: Reflections on the Notion of Voice
}

Sylvie Patron

\section{To cite this version:}

Sylvie Patron. Homonymy, Polysemy, and Synonymy: Reflections on the Notion of Voice. Per Krogh Hansen, Stefan Iversen, Henrik Skov Nielsen et Rolf Reitan. Strange Voices, Berlin, Walter de Gruyter, pp. 13-36, 2011, Narratologia. hal-00698707

\section{HAL Id: hal-00698707 https://hal.science/hal-00698707}

Submitted on 28 Mar 2013

HAL is a multi-disciplinary open access archive for the deposit and dissemination of scientific research documents, whether they are published or not. The documents may come from teaching and research institutions in France or abroad, or from public or private research centers.
L'archive ouverte pluridisciplinaire $\mathbf{H A L}$, est destinée au dépôt et à la diffusion de documents scientifiques de niveau recherche, publiés ou non, émanant des établissements d'enseignement et de recherche français ou étrangers, des laboratoires publics ou privés. 


\title{
Strange Voices \\ in Narrative Fiction
}

\author{
Edited by \\ Per Krogh Hansen \\ Stefan Iversen \\ Henrik Skov Nielsen \\ Rolf Reitan
}

De Gruyter 


\section{SYLVIE PATRON}

(Paris)

\section{Homonymy, Polysemy and Synonymy: Reflections on the Notion of Voice}

[E]very concept should be understood as a stenogram for the questions it makes accessible. Thus it becomes clear that concepts with the same name may in fact be totally different, because they summarize different groups of questions; inversely, concepts with different names may be strictly equivalent, because it becomes clear that the questions they summarize are in fact the same. ${ }^{1}$

\section{Introduction}

This article proposes an investigation of the phenomenon of homonymy (one word, different meanings) in the case of narrative voice, or of voice in narrative theory. It is an accepted fact however that it can be difficult to distinguish between homonymy and polysemy when the meanings compared are neither very distant nor very close. I shall also address the synonyms of the word "voice" in the different narrative theories considered. The article is divided into two parts. The first concerns voice in "communicational" theories of narrative (to use the term employed by S.-Y. Kuro$\mathrm{da}^{2}$ ). Here I analyze the relations of homonymy, polysemy and synonymy surrounding the notion of voice in the theories of Gerrard Genette, Seymour Chatman and Franz K. Stanzel. ${ }^{3}$ I show that there are three different notions of voice in Genette's work which are different in nature and in origin: voice as a category of narrative analysis (forming a system with the two other categories of time and mood, and including the sub-categories of time of narrating ${ }^{4}$, level and person); voice in the chapter on "Mood", or voice

\footnotetext{
Milner 1995: 17-18. (Translation by Susan Nicholls).

See Kuroda 1979b: 205-207 et passim.

See Genette 1983, Genette 1988, Chatman 1980 and Stanzel 1984.

4 [Translators note: All references to translated narratological theories in this article use the published English translations. In order to avoid potential confusion, please note that the
} 
as opposed to mood (reduced to the meaning of person); voice as a synonym of narrative enunciation or narration (confused with discursive enunciation, in other words with enunciation presupposing a speaker and an addressee, or a narrator and a narratee). In my view, the relation between these three notions is merely one of homonymy. I then compare the notion, or notions, of voice in Genettian and post-Genettian narratology with the narrative theories of Chatman (for whom voice is synonymous with verbal expression and/or narratorial expressivity) and Stanzel (who seldom uses the notion of voice, replacing it with that of mediacy, which he defines as the characteristic trait of the narrative genre as opposed to other literary genres). The second part of the article concerns S.-Y. Kuroda and Ann Banfield's critique of communicational theories of narrative in the case of fictional narrative. ${ }^{5}$ Kuroda does not employ the notion of voice, however an implicit critique of the notion can be seen in his critique of John R. Ross's performative analysis, according to which every sentence is derived from an underlying structure containing a performative verb in the first person. Banfield, for her part, demonstrates the inadequacy of what is known as the "dual voice theory" in a certain form of free indirect discourse (represented speech and thought in her own terminology). For Banfield, "As long as a third-person subjectivity is represented, no speaking voice can be realized". "It should be understood that, for Banfield, the author, who is responsible for the representation of speech and thought, is not considered to be a "speaking voice". In conclusion, I question whether it is advisable to retain the notion of voice in narrative theory, since eradicating homonymy and, incidentally, polysemy and multiple synonyms is in my view the first requirement of the logic and even the ethics of any theoretical language.

\section{Voice in Communicational Theories of Narrative}

I will make the same distinction here as in previous work ${ }^{7}$ between communicational theories of narrative, where communication between a narrator and a narratee, be they real or fictional, is constitutive of the definition of narrative, and "non-communicational" theories, which could also

French narration occurs as both "narration" and "narrating" in English, énonciation as both "enunciation" and "enunciating". Other synonymous translations are indicated in the body of the text.]

5 See Kuroda 1979b: 205-216, and Banfield 1982, specifically 183-223.

6 Banfield 1991: 26.

7 See Patron 2009. 
be termed "poetic"s theories of fictional narrative, where fictional narrative, or a certain type of fictional narrative, and communication are two mutually exclusive categories. Communicational theories of narrative are based on a postulate concerning the function of language without developing any linguistic analysis; the non-communicational or poetic theories of fictional narrative considered here are the product of linguists (Kuroda, Banfield) and are founded on a close analysis of the distinctive linguistic features of fictional narrative.

The first four sections of this first part of the article will deal with voice in Genettian narratology, a quintessential communicational theory of narrative.

1. Voice is, first, the name given by Genette in Narrative Discourse to a category of narrative analysis. It is a term lifted from the grammar of verbs and used metaphorically:

I walk, Pierre has come are for me minimal forms of narrative, and inversely the $\mathrm{Od}$ yssey or the Recherche is only, in a certain way, an amplification (in the rhetorical sense) of statements such as Uysses comes home to Ithaca, or Marcel becomes a writer. This perhaps authorizes us to organize, or at any rate to formulate, the problems of analysing narrative discourse according to categories borrowed from the grammar of verbs, categories that I will reduce here to three basic classes of determinations: those dealing with temporal relations between narrative and story, which I will arrange under the heading of tense; those dealing with modalities (forms and degrees) of narrative "representation", and thus with the mood of the narrative; and finally, those dealing with the way in which the narrating itself is implicated in the narrative, narrating in the sense which I have defined it, that is, the narrative situation or its instance, and along with that its two protagonists: the narrator and his audience, real or implied. ${ }^{\text {? }}$

As Genette himself emphasizes, the category of voice might just as easily have been called "person", were it not for the psychological connotations of the word "person" and the fact that Genette saved the term for designating a sub-category of voice. ${ }^{10}$ It might also be considered that mode, as Genette defines it, following Littré ("Name given to the different forms of the verb that are used to affirm more or less the thing in question, and to express [...] the different points of view from which the life or the action is

8 "Poetic" should here be understood as "centred on the work of the author as poietes". The term was coined by Kuroda (see 1979b: 130, 140). It follows certain propositions in Hamburger (see 1993 : 10-13) and was adopted by Banfield (see for example 2003: 479). In my view, several articles in the present issue (see especially Nielsen, Reitan, and Skalin) are variants of or move close to poetic theories of narrative fiction. They are nevertheless distinct by the fact that their reflexions on the foundations of narrative theory do not emanate "from a linguistic point of view".

9 Genette 1983: 30-31.

10 See ibid. 31. 
looked at" ${ }^{\prime 11}$ ) would have been far more apt than voice and, a fortiori, than person for designating "a relation with the subject (and more generally with the instance) of the enunciating". ${ }^{12}$

Voice is defined extremely vaguely as "the mode of action [of the narrative] considered for its relation to the subject [...] who carries out or submits to the action, but also [...] who reports it, and, if need be, all those people who participate, even though passively, in this narrating activity". ${ }^{13}$ It is divided into three sub-categories respectively called the "time of the narrating", the "narrative level" (thereafter simply "level") and "person", with quotation marks (or "relationship" as an occasional variant). Time is thus reintroduced as a "vocal" or "vocalic" determination. ${ }^{14}$ As for embedded or framed narrative (data of level, according to Genette), it could just as easily be considered under the category of mood (or more precisely, of distance) to the extent that it is a question of a form of direct discourse, which tells a story of a certain length. According to Richard Aczel, who sums up the position of the majority of narratologists on this subject, "[...] nothing - except perhaps confusion-is gained by rechristening person, time, and level as 'voice". ${ }^{15}$

2. There is a second notion of voice in Genette, in his chapter on "Mood", where voice appears in opposition to mood (or more precisely, to perspective or focalization). On point of view in fictional narrative, Genette writes:

[...] most of the theoretical works on this subject (which are mainly classifications) suffer from a regrettable confusion between what I call here mood and voice, a confusion between the question who is the character whose point of view orients the narrative perspective? and the very different question who is the narrator?-or, more simply, the question who sees? and the question who speaks? ${ }^{16}$

Here, the word "voice" designates what the chapter on "Voice" describes using the category of person. The question "who speaks?" does indeed require the answer of a "[n]arrator as a character in the story" or a "[n]arrator not a character in the story"17; "who speaks?" is therefore the

11 Ibid. 31, n. 9. The elision is Genette's.

12 Ibid. 31-32.

13 Ibid. 213. My replacement "of the verb" with "of the narrative" in the quotation from Joseph Vendryès; my linking of the quote to the commentary that follows.

14 The adjectives "vocal" and "vocalic" appear in Genette $(1988: 78,112,113)$ solely in relation to voice 2 .

15 Aczel 1998: 468. To my knowledge, only Jean-Marie Schaeffer (see 1999: 722-727) uses voice in the sense of Genette's voice 1.

16 Genette 1983: 186.

17 Ibid. See also ibid. 244-245, 248, where these two types of narrative, and therefore narrators, are named, respectively, "homodiegetic" and "heterodiegetic". 
equivalent of "is the person speaking a character in the story or not?". It is noteworthy that there is no true parallel between the answer to the question "who sees?" and the reply to the question "who speaks?". If, for Genette, the answer to the question "who sees?" might be "nobody" (nonfocalized narrative or narrative with zero focalization), the answer to the question "who speaks?" is nevertheless always "somebody" (there are no "non-vocalized"18 narratives or narratives with "zero vocalization").

The reduction of the notion of voice to a question of person, that is, to the homodiegetic or heterodiegetic nature of the narrator, is confirmed in Narrative Discourse Revisited, when Genette refers to "vocal' selection", "vocalic positions" or "vocalic choice", and to "transvocalization" to designate the choice of homodiegeticity or heterodiegeticity, and the transition from one to the other in certain real or imaginary experiences. ${ }^{19}$ Voice is also reduced to person by Shlomith Rimmon-Kenan, who distinguishes between narrative levels on one hand, and voices on the other ("Narration: levels and voices" 20 ), and who defines voice as "the narrator's position vis a vis the story, in the spirit of Genette". ${ }^{21}$ In general, this second notion of voice has met with far more success than the preceding one. As Monika Fludernik writes, "in the reception of Genette's work $[\ldots]$, the formula of 'who sees' (focalization) versus 'who speaks' (person, voice) $[\ldots]$ has become the hub on which narratology is supposed to turn". 22

3. There is a third notion of voice in Genette, which is synonymous with narrative enunciation or what he calls "narration" ("narrating" in the English translation). At the end of his chapter on "Mood", Genette writes:

Again and again we have seen this subversion of mood tied to the activity, or rather the presence, of the narrator himself, the disturbing intervention of the narrative source - of the narrating in the narrative. It is this last instance-that of voice - which we must now look at for its own sake, after having met it so often without wanting to. ${ }^{23}$

In the first sentence of this quote, substituting the word "voice" for the word "narrating" would result in a statement with exactly the same meaning as the original. The same is true in other contexts, if not in all of them (for example: "Of course, these signs of the organization of the narrative

18 The verb "to vocalize" is used in Genette 1988: 112.

19 See ibid. 78, 109, 112, 113. The adjective "vocal" is not used in quotation marks in Genette 2007: 352 .

20 Rimmon-Kenan 2002: 87-106.

21 Rimmon-Kenan 1989: 159.

22 Fludernik 2001: 620.

23 Genette 1983: 211. 
are in themselves marks of the instance of narrating, which we will meet again as such in the chapter on voice"; "It seems that poetics is experiencing a comparable difficulty in approaching the generating instance of narrative discourse, an instance for which we have reserved the parallel term narrating"24; "[...] the main point of Narrative Discourse, beginning with its title, reflects the assumption that there is an enunciating instance - the narrating - with its narrator, and its narratee, fictive or not, represented or not, silent or chatty, but always present in what is indeed for me, I fear, an act of communication"25). We are therefore justified in speaking of synonymy, or at least of near synonymy, between voice and narrative instance or narrating. In the reception of Genette's work, this synonymy has occasionally been pointed out. Rimmon-Kenan writes, for example, that: "Indeed, the category of narration (or 'narrating' in English translation) becomes one aspect of the récit (i.e. 'voice'), so that the ternary model is turned in practice into a binary one." 26 Dan Shen goes one step further: "Although Genette stresses the importance of 'narrating' and expresses his regret at the fact that 'until now the theory of narrative has been so little concerned with the problems of narrative enunciating', his trichotomous distinction becomes a dichotomy between story and discourse in practice, as Rimmon-Kenan observes, Indeed, the category of narration [etc.]'." ${ }^{27}$ It is worth specifying that, for Genette, narrative enunciation or narration corresponds to what Émile Benveniste calls "énonciation de discours" ("utterance of discourse" in the English translation), which he associates with the use of tenses of discourse, notably the perfect tense, when it is a question of telling a story. ${ }^{28}$ For Genette, all narration is a form of "utterance assuming a speaker and a hearer"; it is a genre "in which someone addresses himself to someone, proclaims himself as a speaker, and organizes what he says in the category of person" 29 - whatever the verbal tenses used. ${ }^{30}$

However, if voice is synonymous with narrative enunciation or narration, in the sense of discursive enunciation or narration, emanating from a narrator who, in the case of fictional narrative, is different from the author, then all of the data referred to in all of the chapters, and not simply those in the chapter on "Voice", can be considered as data pertaining to

24 Ibid. 78, n. 107, 213.

25 Genette 1988: 101.

26 Rimmon-Kenan 1989: 159.

27 Shen 2001: 123.

28 See Benveniste 1971: 211 and 308, n. 10.

29 Ibid. 209.

30 See Genette 1982: 138-143, and 1988, 99. For a different reading of Benveniste, see Kuroda 1979b: 211-212, 217-218, and 228, and Banfield 1982: 141-180. See also Patron 2011. 
voice and therefore associated to the activity of a narrator. This is quite clearly the case in the footnote quoted previously: "Of course, these signs of the organization of the narrative [the marks of the end of the prolepsis] are in themselves marks of the instance of narrating, which we will meet again as such in the chapter on voice" 31 , or in the following remark from the chapter "Voice" (in the section concerning the functions of the narrator): "[...] the narrator can refer to [the narrative text] in a discourse that is to some extent metalinguistic (metanarrative, in this case) to mark its articulations, connections, interrelationships, in short, its internal organization [...]." "32 It can also be seen in numerous passages from the chapters on "Order", "Duration", "Mood" and "Voice" (for example: "[...] the narrator, having evoked the quarrel between Achilles and Agamemnon that he proclaims as the starting point of his narrative [...] goes back about ten days to reveal the cause of the quarrel in some 140 retrospective lines $[\ldots .$.$] "; "[...] the narrator, forsaking the course of the story [...] makes it his$ business, in his own name and solely for the information of his reader, to describe a scene that at this point in the story no one, strictly speaking, is looking at"; "[...] thoughts and feelings are no different from speech, except when the narrator undertakes to condense them into events and to relate them as such"; "Here we are typically in external focalization, because of the narrator's marked ignorance with respect to the hero's real thoughts"; "The real question is whether or not the narrator can use the first person to designate one of his characters" "33). As Nils Soelberg wrote in his review of Narrative Discourse Revisited, "it is the narrator who selects, temporalizes, modalizes, vocalizes and valorizes in and through his narrating." 34 Viewed from this perspective, everything is subordinated to voice, which means that all the "signs of the organization", but also all the data of the organization of the narrative can be analyzed within a unified vision in the light of enunciative parameters (subject and situation of enunciation, in the sense of a subjectivity and a situation of enunciation differing from those of the author).

4. At this point, we are within our rights to wonder whether "voice 1", "voice 2" and "voice 3" are three homonyms, or whether they correspond to three meanings of one polysemic word. According to their objectives and theoretical choices, commentators tend either to emphasize the unity of the meanings (polysemic tendency) or to see the differences as incommensurable (homonymic tendency). Genette quite naturally illustrates the

31 Genette 1983: 78, n. 107.

32 Ibid. 255.

33 Ibid. 36, 100, 171, 194, 244. See also Genette 1988: 35, 58, 73, 75, 81-82.

34 Soelberg 1984: 126. (Translation by Susan Nicholls). 
first tendency in his introduction and in the first section of his chapter on "Voice" (to which the page numbers listed under "Voice" in the index refer): "[The last determinations are] those dealing with the way in which the narrating itself is implicated in the narrative, narrating in the sense which I have defined it, that is, the narrative situation or its instance, and along with that its two protagonists: the narrator and his audience, real or implied", 35 " "...] for us voice [...] will refer to a relation with the subject (and more generally with the instance) of the enunciating [...]";36 "[There is] a tight web of connections among the narrating act, its protagonists, its spatio-temporal determinations, its relationship to the other narrating situations involved in the same narrative, etc. [...] we will look successively at elements of definition whose actual functioning is simultaneous: we will attach these elements, for the most part, to the categories of time of narrating, narrative level, and 'person' (that is, relations between the narrator-plus, should the occasion arise, his or their narratee[s] —and the story he tells)." ${ }^{37}$ In the same way, Fludernik emphasizes the links between voice 2 and voice 3 when she writes that: "The term voice in narratology has been coined in connection with the question 'who speaks?' (Genette), usually in distinction from the narrative categories of perspective or point of view (Genette's Mood), which correlate with 'who sees?'. An analysis of 'who speaks?' is patently predicated on a communicative model of narration in which the words of the text have to be uttered, i.e. enunciated, by a narrative instance, either the narrator or a character". ${ }^{38}$ Aczel, on the other hand, illustrates the homonymic tendency ("[...] nothing-except perhaps confusion - is gained by rechristening person, time, and level as 'voice"'39).

For my part, I would tend to emphasize the differences rather than the similarities between voice 1 , voice 2 and voice 3 . Differences, firstly, in terms of their origin: a grammatical metaphor for voice 1 (the term of comparison being voice in the sense of grammatical voice, a homonym but not a synonym of the human voice); an interpretation of the difference between fictional narratives in the first person and in the third person for voice 2; Benveniste's enunciative linguistics, including a revision of the opposition he established between historical enunciation and the discursive enunciation, for voice 3. Differences, too, in their nature: a formulation, and a relatively arbitrary one at that, of certain determinations of narrative for voice 1 ; the summary of a series of theoretical questions for voice 2 and voice 3 . Voice 2 sums up the question of the primacy

35 Genette 1983: 31.

36 Ibid. 31-32.

37 Ibid. 31, 31-32, and 215.

38 Fludernik 1993: 325.

39 Aczel 1998: 468. 
of "diegetic" (homodiegetic or heterodiegetic) in preference to linguistic factors in Genette's work, and the question of the independence of person, in the diegetic sense, and of focalization in fictional narrative. Voice 3 sums up the question of the application of interlocutory linguistics to all fictional narrative. ${ }^{40}$

5. In Story and Discourse, Chatman does not use the notion of voice in the sense of Genette's voice 1. He does not resort to grammatical metaphors to formulate the problems of analyzing fictional narrative (composed of story and discourse, in his own terminology). He considers narrative time under the category of discourse-time in the chapter "Story: events" (in the section devoted to time and plot). ${ }^{41}$ Neither person, nor narrative level, is assigned a separate section. ${ }^{42}$ The relations between Chatman's voice and Genette's voice 2 and 3 are rather more complex.

Chatman first explains the notion of voice via a distinction: "Point of View and Its Relation to Narrative Voice" (the page numbers under "Voice" in the index refer to this section). Point of view is defined as "the physical place or ideological situation or practical life-orientation to which narrative events stand in relation", and voice as "the speech or other overt means through which events and existents are communicated to the audience". ${ }^{43}$ Other synonyms are proposed for the word "voice": "expression", "means of communication" (or, more exactly, "the medium through which perception, conception, and everything else are communicated"), or yet again, "verbaliz[ation]". ${ }^{44}$ When Chatman writes that "[p]oint of view does not mean expression; it only means the perspective in terms of which the expression is made. The perspective and the expression

40 Taking advantage of rereading my article, I should add that Liesbeth Korthals Altes (see 2006: 168) speaks of what I term Genette's voice 1 and voice 2 in terms of a "slide" from one to the other (and from there to "a psychological notion of personality", a formulation which I find slightly problematic given Genette's anti-psychological standpoint). However, she does not consider what I term voice 3 in Genette and makes no mention of the opposition between Benveniste's historical enunciation and discursive enunciation (see ibid. 168 on Genette and 169-170, on enunciative linguistics, called "discourse linguistics"). I would like to thank the editors of Strange Voices for mentioning this article to me.

41 Chatman 1980: 63. See also ibid. 80-84 (section devoted to the way temporal distinctions are manifested).

42 Embedded or framed narrative is mentioned in the chapter on "Discourse: Covert versus Overt Narrators", in the section devoted to the narratee (ibid. 254-256, 258). Person is briefly alluded to in the chapter on "Discourse: Non-narrated Stories", in the section devoted to

point of view and its relation to narrative voice (ibid. 155).

43 Ibid. 153.

44 Ibid. 154, 156. It can be noted that, in his introduction, Chatman also defines discourse as "the expression, the means by which the content is communicated" (ibid. 19). 
need not be lodged in the same person" ${ }^{35}$, he is close to Genette and his opposition between the questions "who is the character whose point of view orients the narrative perspective?" and "who is the narrator?"46 (as long, of course, as we overlook the fact that "who is the narrator?" means "is the narrator homodiegetic, or heterodiegetic?). Like Genette, Chatman uses the verb "to voice" ("limited third person point of view voiced by a covert narrator", "limited third person point of view voiced by an overt narrator" ${ }^{37}$ ) in contrast to the verbs "to see" or "to perceive", which are reserved for the character who is the source of point of view. ${ }^{48}$ Chatman, however, distances himself from Genette in his use of the terms "homodiegetic" and "heterodiegetic". In fact, for Chatman, the adjective "homodiegetic" can only be applied to characters (including the "I as character" of first-person fictional narratives): "It makes sense to say that the character is literally perceiving something within the world of the work ('homodiegetically', as Genette would say)". ${ }^{49}$ The narrator, for his part, is always heterodiegetic (including the "I as narrator" of first-person fictional narratives): "But what the narrator reports from his perspective is almost always outside the story (heterodiegetic), even if only retrospective, that is, temporally distant. Typically, he is looking back at his own earlier perception-as-acharacter. But that looking-back is a conception, not a perception. The completely external narrator presents an even more purely conceptual view. He never was in the world of the work: discourse-time is not a later extension of story-time". ${ }^{50}$ This position is explained by the substantializing of the levels of story and discourse which, to begin with, were purely operative $^{51}$ (Chatman also writes that "point of view is in the story [...], but voice is always outside, in the discourse" 52 ).

For Chatman, voice (by implication, the voice of the narrator) also contrasts with the absence of voice that characterizes the implied author: "Unlike the narrator, the implied author can tell us nothing. He, or better, it has no voice, no direct means of communicating. It instructs us silently, through the design of the whole, with all the voices, by all the means it has chosen to let us learn." ${ }^{33}$ It may appear surprising that this instance with no voice, that is, with no means of communicating, is shown as an ad-

\footnotetext{
45 Ibid. 153. Chatman's emphasis.

46 Genette 1983: 186.

47 Chatman 1980: 154

48 Ibid. 155.

49 Ibid.

50 Ibid.

51 See ibid. 19-26, 31 and especially 37.

52 Ibid. 154.

53 Ibid. 148.
} 
dresser in the diagram of narrative communication situations on p. $151 .{ }^{54}$ Should the implied author be seen as addressing the reader, or the implicit reader, using the narrator as intermediary? If so, what happens when there is no narrator (in "nonnarrated" stories, as Chatman terms them) ${ }^{55}$ )? Chatman provides no answers to these questions.

There is a second notion of voice in Chatman's work which, strangely, includes the absence of voice or of "audibility" of the voice: "the concept of narrator's voice (including its 'absence')"; "the concept of narrator's voice-including the case where one is 'not' (or minimally) present"; "[...] the separate narrating voice may or may not make itself heard." 56 "The voice (or audibility of the voice, or audibility of the narrator, or narratorpresence, or narrator-prominence-all these expressions are synonymous) is seen as a spectrum of possibilities going from non-audibility to maximum audibility via the adjunction of characteristic traits of audibility: "[...] the more identifying features, the stronger our sense of a narrator's presence. The 'non'- or minimally narrated story is simply one in which no or very few such features occur." 57 The characteristic traits of audibility are listed as follows: use of indirect discourse and free indirect discourse; presence of phenomena of presupposition; "limited omniscience" (points of view and shifting of point of view); descriptions; narrative summaries; reports of what characters did not think or say; interpretative commentaries. ${ }^{58}$ As is apparent, these traits are quite heterogeneous ${ }^{59}$; they involve concerns, which are rhetorical or stylistic (the opposition between direct and indirect discourse which are in fact called direct and indirect "styles"), pragmatic in the sense of pragmatic linguistics (presupposition), related to "classical" narrative theory (point of view, the opposition between scene and summary, etc.). ${ }^{60}$ Chatman does not include a properly linguistic dimension in his spectrum: the presence of first-person pronouns only appears at the end: "Commentary, since it is gratuitous, conveys the overt

54 This observation has already been made by Rimmon-Kenan: see 2002: 89. On Chatman's diagram of the narrative communication situation, see also Brenkman 2000: 290-291, 292, 295.

Chatman 1980: 34, 166-195.

56 Ibid. 147, 151, 154.

57 Ibid. 196. See also ibid.: 166-194, for the definition and description of "nonnarrated stories" ("written records", "speech records", "interior monologue", etc.).

58 Aczel 1998: 470 reproaches Chatman for not having included style, defined as "narratorial idiom", in his list of characteristic traits of voice.

59 The addition of style, however it is defined, would only extend their heterogeneity. For a non-expressive definition of style, see Philippe (2005).

60 See Patron 2009: 68-76 for a critical presentation of each of these characteristics. 
narrator's voice more distinctly than any feature short of explicit selfmention." 61

6. Stanzel, in his $A$ Theory of Narrative, does not use the notion of voice in the sense of Genette's voice 1 either. He does not resort to grammatical metaphors for the formulation of the problems of analyzing fictional narrative discourse. He addresses the problem of narrative time in chapter 2, "Zero grades of mediacy: synopsis, chapter heading, outline" 62 , and touches briefly on it, under the category of "narrative distance", in Chapter 4, "The opposition person", in the sections on the "embodiment" of the narrator in first-person fictional narrative and its consequences for the interpretation of narrative..$^{63}$ It should be noted that Stanzel uses the term "person" in a similar sense to Genette ("identity and non-identity of the realms of the narrator and the fictional characters"). ${ }^{64}$ However, for Stanzel, person forms a system with perspective and mode, which constitute the two other aspects or elements of the narrative situation. There is no relation, in his view, between person, time and narrative level, nor does he devote separate chapters or sections to the problem of narrative level.

Stanzel begins the first chapter of his work with the affirmation that "[w]henever a piece of news is conveyed, whenever something is reported, there is a mediator - the voice of a narrator is audible", only to add immediately afterward: "I term this phenomenon 'mediacy' (Mittelbarkeit). Mediacy is the generic characteristic which distinguishes narration from other forms of literary art." ${ }^{65}$ What Stanzel says about mediacy can therefore be applied to voice, or to the audibility of voice: it has "two manifestations": the "overt mediacy of narration and that covert or dissimulated mediacy which produces the illusion of immediacy in the reader". ${ }^{66}$ Here we can recognize Chatman's voice 2, only minus any "absence of voice", which corresponds to narratives which Stanzel does not consider, or does not consider from this perspective, and minus the list of characteristics traits of audibility. In the absence of such a list, statements affirming that the "voice of a narrator" is "still" or "no longer audible" in such and such a narrative, or "more audible" in a particular sentence of a narrative than

61 Chatman 1980: 228. In his conclusion, Chatman wonders what narrative theory might be able to do "with recent views of pronominal structure and the whole subject of deixis" (ibid. 264).

62 Stanzel 1984: 23-28, 32, 40-45.

63 Ibid. 93-94, 95-97.

64 Ibid. 79.

65 Ibid. 4.

66 Ibid. 141. "Covert or dissimulated mediacy" corresponds to the figural narrative situation, that is, to "point-of-view narratives". 
in another, seem even more arbitrary in Stanzel's text than they do in Chatman's. ${ }^{67}$

\section{Voice and Kuroda, and Banfield's Critique of Communicational Theories of Fictional Narrative}

7. In his articles on narrative theory, Kuroda does not use the notion of voice, however, a critique of the notion is implied in his critique of John R. Ross's performative analysis applied to sentences of point-of-view narratives. ${ }^{68}$ Kuroda begins by establishing a system of relations between:

- the communicational theory of linguistic performance: according to this theory, every linguistic performance is an act of communication, thus implying an addressor, an addressee, a message and a code common to both addressor and addressee;

- the communicational theory of linguistic competence. this theory includes the communicational theory of linguistic performance; it was represented, in its day, by Ross's performative theory, also termed "performative analysis"; according to this theory, every sentence is derived from an underlying structure containing a performative verb in the first person;

- the communicational theory of narrative: narrative being a form of linguistic performance, the communicational theory of narrative must also be a form or an application of the communicational theory of linguistic performance. Kuroda quotes the following sentence from Roland Barthes' "Introduction to the Structural Analysis of Narrative": "[...] narrative as object is the point of a communication: there is a donor of the narrative and a receiver of the narrative. In linguistic communication, $j e$ and $t u$ ( $I$ and you) are absolutely presupposed by one another; similarly there can be no narrative without a narrator and a listener (or reader)." ${ }^{69}$ For Kuroda, this quote is an example of a statement of the most explicit and frank kind, according to which a theory of narration having recourse to the no-

67 See ibid. 9, 58-59, 112, 198. As far as posterity is concerned for Genette, Chatman and Stanzel, I would subscribe to the assertion made by Korthals Altes (2006: 167) according to which "[v]oice in narratology has been made to mean everything and its opposite". However I am surprised that after making such an assertion, she herself endeavours to rehabilitate the idea, which competes with much better constructed linguistic or pragmatic formulations (for example "linguistic subjectivity", "represented speech and thought" [Banfield], "irony as echoic mention" [Sperber and Wilson]).

68 See Kuroda 1979b: 205-210.

69 Barthes 1973: 110. In another passage of his article, Barthes introduces the term "narrataire" ("narratee") to designate the addressee of the narrator. Kuroda does not adopt this term although he occasionally mentions an "imaginary addressee" differing from the reader (see Kuroda, 1979b: 223). 
tion of narrator must have its theoretical basis in the communicational theory of linguistic performance. ${ }^{70}$

Narrative theory having recourse to the notion of narrator (or the "narrator theory of narration" "11) thus implies that every sentence of the narrative should be considered as a message communicated by the narrator to the addressee (narratee or reader). This hypothesis is compatible with performative analysis. It would suffice to say that the narrator is the referent of the "I", the subject of the performative verb underlying each sentence of the story:

I (the narrator) assert, tell, etc. to you (the narratee) that $S$.

This is precisely the claim made by Genette regarding what, in his view, constitutes the invariant element of the narrative situation: "to wit, the presence (explicit or implicit) of the 'person' of the narrator": "This presence is invariant because the narrator can be in the narrative (like every subject of an enunciating in his enunciated statement) only in the 'first person'. [...] Insofar as the narrator can at any instant intervene as such in the narrative, every narrating is, by definition, to all intents and purposes presented in the first person [...]." ${ }^{72}$

A problem is raised, however, by sentences from third-person fictional narratives which are supposed to represent the point of view of one or several characters (that is, the thoughts, feelings or perceptions of the character or characters). Obviously, the representation of the profound structure conforming to performative analysis-with a first-person subject and second-person indirect object of a performative verb such as "assert", "tell", etc.- does not suit this kind of sentence if the first-person subject is to be interpreted referentially as the source of point of view (that is, of thoughts, feelings or perceptions):

*I (referentially a character of the story) thought, felt, perceived, etc. to you (the narratee) that $S$.

This is the claim made, in a different way, by Chatman and Stanzel about the character who is the source of point of view: "It is simply a mistake to argue that Lenehan is in any sense the 'narrator' of 'Two Gallants'. When he speculates, reminisces, or whatever, he is not telling a story to anybody, not even himself" "73; "By contrast [with the teller-character], a reflector-

70 See ibid. 206. Other examples of open, explicit communicationalist statements may be found in Genette (see 1983: 260, and 1988, 101) and Rimmon-Kenan (see 2002: 88-89).

71 Kuroda 1979b: 206.

72 Genette 1983: 243-245. Other non-theorized expressions of the correspondence between narratological analysis and performative analysis can be found in the work of Gerald Prince (see 1982: 7-8 and 16-17) and Mieke Bal (see 2004: 21-22). For a theorized analysis of the correspondence, see Marie-Laure Ryan 1981.

73 Chatman 1980: 198. 
character reflects, that is, he mirrors events of the outer world in his consciousness, perceives, feels, registers, but always silently, because he never 'narrates', that is, he does not verbalize his perceptions, thoughts and feelings in an attempt to communicate them." ${ }^{74}$ Kuroda also considers the possibility of combining performative analysis with an analysis through direct or indirect speech, which would lead to representations of the following type:

I (the narrator) assert, tell, etc. to you (the reader): John thought, felt, etc.: "S".

I (the narrator) assert, tell, etc. to you (the reader): John thought, felt, etc. that $S$.

The question boils down to knowing how the narrator can make assertions concerning the propositional content of inner acts such as thinking, feeling, etc. As Kuroda writes, " $[\mathrm{g}]$ rammatically speaking, we do not know the grounds on which the narrator makes his assertions about the inner acts of characters. But we must, so long as we follow the performative analysis, accept that he does make such assertions. One could just assume that he directly perceives the mental states of his characters. Thus we are led to the notion of an omniscient narrator." 75 For Kuroda, the need to admit, first, the theoretical existence of an omniscient narrator, and second, that the omniscient narrator speaks using a peculiar syntax of his own, is too high a price to pay for accounting for facts which could easily be explained in another way. ${ }^{76}$

8. In Unspeakable Sentences: Narration and Representation in the Language of Fiction, Banfield demonstrates the inadequacy of what is known as the "dual voice theory" in a certain form of free indirect discourse, in the third person and in the past tense (represented speech and thought in her own terminology). Her demonstration involves three stages. ${ }^{77}$ First stage: Banfield examines the similarities and differences between the forms of direct and indirect discourse and establishes the impossibility of switching from one to the other by any plausible grammatical transformation (this point is based mainly on the existence, in direct discourse, of elements and constructions which become inacceptable in indirect discourse). Second stage:

74 Stanzel 1984: 144.

75 Kuroda 1979b: 210.

76 See Kuroda 1979a: 190-199, 1979b: 216-223, and 1979c: 10-11. See also Patron 2009: $177-$ 202 for an overview of Kuroda's narrative theory.

77 This passage summarizes part of the chapter on Banfield in Patron 2009: 203-218. My presentation differs markedly from Aczel's (1998: 484-488), which does not take Banfield's linguistic argument into account, and which uses substantialized narratological concepts (voice, focalization). It also differs from that by Korthals Altes 2006: 173, which does not take Banfield's linguistic argumentation into account either, and adopts Fludernik's (1993) assertions on pragmatics "surpassing" linguistics without critical appraisal. 
Banfield replaces the transformational hypothesis with a syntagmatic one, that is with a series of different rewriting rules for direct or indirect discourse, introducing a new initial symbol, E (for "expression", in the narrow sense of "expression of subjectivity"), to replace $S$ as the initial symbol of the basic rules. Unlike $S, E$ is not recursive. It is associated with a principle of interpretation, which Banfield formulates in the following way:

$1 \mathrm{E} / 1 \mathrm{I}$ : For every expression (E), there is a unique referent of $I$ (the SPEAKER), to whom all expressive elements are attributed, and a unique referent of you (the ADDRESSEE/HEARER) ${ }^{78}$

This principle explains why the referents of the pronouns "I" and "you" can be different in the two propositions of a sentence in direct discourse, but must remain the same in the two propositions of a sentence in indirect discourse. It also explains why the "style", that is, the series of expressive elements and constructions, as well as the language or dialect can be different in the two propositions of a sentence of direct discourse, but must be of the same kind in the two propositions of a sentence in indirect discourse. The expressive elements and constructions are defined in a strict manner on exclusively syntactic grounds. It is a matter, firstly, of non-embeddable elements and constructions appearing in the second proposition of direct discourse, but not in that of indirect discourse (interjections, exclamatory sentences and exclamatory constructions with no verb, incomplete sentences); secondly, of embeddable elements which, when they appear in the second proposition of indirect discourse, are always attributed to the speaker of the whole, that is, to the person quoting and not to the person quoted (first- and second-person personal pronouns, deictic adverbs of time and place, "qualitative nouns" such as "idiot" in "that idiot of a doctor", evaluative adjectives like "poor", terms expressing relationship, such as "Mummy"). In a third stage, Banfield observes that represented speech and thought are distinct from forms of direct discourse and indirect discourse, and cannot be derived from the underlying structures of the two forms of reported speech either. Like the sentences of direct discourse, the sentences of represented speech and thought are E expressions: they have the same syntactical properties, notably that of not being able to be embedded in other sentences; they can contain interjections, exclamatory sentences and constructions, incomplete sentences, etc. This is evident in the following example, taken from Mrs Dalloway: "No, no, no! He was not in love with her any more!"79 In sentences of this sort, the previously asserted relation between the first person and the expression of

$\begin{array}{ll}78 & \text { Banfield 1982: } 57 . \\ 79 & \text { Woolf 1996: 85. }\end{array}$ 
subjectivity no longer holds. It is therefore necessary to reformulate the principle " $1 \mathrm{E} / 1 \mathrm{I}$ ", by decomposing it into two principles, of which only one relates the first person and the expression of subjectivity.

1 E/1 SELF: For every node E, there is at most one referent, called the "subject of consciousness" or SELF, to whom all expressive elements are attributed. That is, all realizations of SELF in an E are coreferential.

Priority of SPEAKER. If there is an I, I is co-referential with the SELF. In the absence of an I, a third person pronoun may be interpreted as SELF. ${ }^{80}$

Following the first principle, the personal pronouns "he" or "she" can take on the role that ordinary discourse normally reserves for the pronoun "I", which is the role of source of subjectivity. This is the case, for example, in "No, no, no! He was not in love with her any more!". Following the second principle, the presence of a speaker who refers to him or herself as "I" necessarily implies that of a subject of consciousness co-referential with "I"; but in the other sentences of represented speech and thought, those which possess a subject of consciousness referred to as "he" or "she", the first person is excluded. This can be verified using simple tests. In the sentence, or sentences, "No, no, no! He was not in love with her any more!", the exclamation is attributed to "he", referring to Peter Walsh. But if we add an "I", which would produce something along the lines of: "No, no, no! He was not in love with her any more, nor with me!", then the exclamation must be attributed, not to Peter Walsh, but to the referent of the first-person pronoun; there is no longer any trace of a subject of consciousness referred to as a third-person pronoun. Banfield concludes: "[...] linguistic argumentation has led to some surprising conclusions for literary theory. Since no first person may appear in represented speech and thought except one interpretable as the E's SELF and since that first person must also appear in any parenthetical attached to the represented E, this means that represented Es cannot be simultaneously attributed to a covert or 'effaced' narrator. Rather than being narrated, consciousness in this style is represented unmediated by any judging point of view." $" 81$

This approach to free indirect discourse may appear counter-intuitive to the extent that it is at odds with the usual way in which theoreticians and critics account for the same sentences or passages. According to the usual approach, free indirect discourse is founded on the mixing or fusion

80 Banfield 1982: 93. The term "subject of consciousness" comes from Kuroda (see Kuroda 1979b: 208, and Banfield 1973: 30, n. 22). On the level of the narrative or of the passage of the narrative, the subject of consciousness who is co-referential with a third-person pronoun is the equivalent of the focal character, the reflector-character or the character who is the source of the point of view in the theories of Genette, Stanzel and Chatman.

Banfield 1982: 97. 
of two voices: the voice of the author or narrator, and the voice of the character. Apart from the epistemological vagaries surrounding the notion of voice, the dual voice approach has the following drawbacks:

- it places all the elements attributed to the narrator, i.e. the third person and the past (for example, the "he" and the past in "No, no, no! He was not in love with her any more!"), as well as the expressive elements defined by Banfield on a strict syntactical basis (for example, the interjection "No, no, no!" and the exclamatory modality), on the same level. To evaluate whether this treatment is justified, it is worth considering the consequences, the most general one being that the domain of expressivity or of the expression of subjectivity becomes unlimited. It includes, notably, all personal pronouns and all verb tense forms in the language. On the other hand, the notion of expression of subjectivity is rendered useless; in particular, it can no longer be used to explain the syntactical differences between direct discourse and indirect discourse;

- it ignores the principle of the priority of the first person as subject of consciousness, as well as the test allowing the justification of this principle ("No, no, no! He was not in love with her any more!", i. e. "No, no, no! He was not in love with her any more! thought Peter" vs. "No, no! He was not in love with her any more, nor with me!", i. e. "No, no! He was not in love with her any more, nor with me! thought I");

- it ignores, therefore, the dissymmetry between first-person free indirect discourse sentences (with a first-person subject of consciousness coreferential with the "I" of the tag, if there is one) and third-person free indirect discourse sentences (with a third-person subject of consciousness co-referential with the "he" or "she" of the tag, if there is one, the presence of which would exclude that of a speaker referred to as "I").

The usual approach, via the dual voice, can also be criticized for: - having a vague, informal view of the duality or mix of voices;

- in particular, for not seeing that when a third-person subject of consciousness is found in one or several sentences of a first-person fictional narrative, on the syntactical level it is a matter of sentences of third-person free indirect discourse (for example: "His life had been confused and disordered since then, but if he could once return to a certain starting place and go over it all slowly, he could find out what thing was...."82). Nothing in fact prevents an author from using sentences of third-person free indirect discourse in a fictional narrative which can be characterized, globally, as a first-person fictional narrative. ${ }^{83}$

82 Scott Fitzgerald (1991: 86).

83 This remark can be extended to whole passages of narratives. In my view, narrative theory has no need of the notion of "impersonal voice" (see Henrik Skov Nielsen 2004, specifically 138-143, and also in the present issue) for an explanation of such passages. It is worth com- 
It may of course be thought that the role of syntax in the analysis of free indirect style is more limited than Banfield claims, and that certain properties of sentences in free indirect style are the remit of semantic or pragmatic studies (which Banfield in fact recognizes herself in the case of irony ${ }^{84}$ ). This does not mean however that Banfield's syntactic analyzes can be ignored, any more than the linguistic and literary conclusions she draws from them.

9. It can be seen that, in her critique of the dual voice theory, Banfield uses the notion of voice in the sense of the presence of a speaker who is referred to, or could be referred to, as "I" and to whom all the expressive elements of the sentences are attributed. This is the meaning to which most of the occurrences of the word "voice" refer in Unspeakable Sentenc$e s^{85}$ (leaving aside those occurrences where the word is mentioned- rather than used-as in the "dual voice theory" ${ }^{86}$ ). This meaning is encountered in "L'écriture et le non-dit", an article written several years after Unspeakable Sentences, in which Banfield replies to the critiques of the French linguist Oswald Ducrot. The following are significant examples: "[...] the crucial issue does not turn on whether an utterance is restricted to one or more than one 'voice' but on whether every utterance must have a 'voice"'87 (in this quotation, the first occurrence is a mention of Ducrot, while the second could be paraphrased by "a voice according to the strict definition of the word"); "As long as a third person subjectivity is represented, no speaking voice can be realized" 88 ; "That the author's role in writing, in composing, need not, cannot, receive a linguistic representation unified around the notion of a voice does not, however, seem to have occurred to Ducrot, and he can conceive of him only as in some way 'speaking' in the text, even if he never says ' $I$ ', unless it is to represent a fictional persona". ${ }^{89}$

It can also be perceived that the author, who is responsible for the third-person representation of subjectivity or for the creation of a narrator in a first-person fictional narrative, is never considered as a voice, or as possessing a voice: "All parts of the text are composed by the author, but their relation to their creator is different from their textual relation to any

paring the use of this notion taken from Maurice Blanchot in Nielsen (see 2004: 139-140 et passim) and Banfield (see 1985: 8-13).

84 See Banfield 1982: 220-223. See also Fludernik 1993: 350-356, 359, Gibson 1996: 149-151, and Korthals Altes 2006: 177-181 et passim.

85 See Banfield 1982: 10, 184, 188, 222, 250, 279.

86 See ibid. 69, 185, 189, 211.

87 Banfield 1991: 23.

88 Ibid. 25.

89 Ibid. 27. 
fictional subject of consciousness or speaker. The text speaks, not the author in it. He has written it, which [...] is a very different act from speaking"90; "[...] an author who is not directly embodied in a first person, as a speaker is in his speech, may manipulate language in accordance with the possibilities inherent in it-and at the same time respecting the limits it imposes, in order to represent a fictional subjectivity - but he does not speak in it. He writes, rather, and in writing disappears". ${ }^{91}$ A connection can be made between Banfield's author and Chatman's implied author (as long as we overlook the fact that Chatman's implied author is considered as an agent of his "diagram of the narrative communication situation").

There is a second, more restrictive notion of voice in Banfield's work, which is voice in the sense of the presence of a speaker who is referred to as "I", and to whom all the expressive elements of the sentences are attributed within a situation of communication, be it real or fictional. This is the meaning to which the following occurrences of the word "voice" refer in Unspeakable Sentences: "What seems to be excluded from represented Es is the rendering of the speaking voice" 92 (meaning: the rendering of the speaking voice by indications of pronunciation); "The language of narration has no accent, because its narrator has no voice" guage of narration in third-person and "classic" first-person fictional narratives; "[...] the only place for representations of the speaking voice within a narrative text is really in some sense outside of it. Its boundaries are set by a graphic notation with no phonetic realization-inverted commas [...]" ${ }^{94}$ Voice can only be used in this sense for characters for which the author creates speeches by means of direct discourse and for the narrator of the type of first-person fictional narrative which Banfield calls "skaz" or "skaz-narrative". 95

10. A final remark: Banfield is right to say, in the article already cited, that "the choice between the two competing models [Ducrot's and her own] will depend on argumentation appealing to the evidence", but that "the issues have taken on an ideological coloring" and that "it suffices to name one position 'unitary' and the other 'polyphonic' for it to appear that the sides are chosen". 96 This promotion of polyphony rather than what could,

\footnotetext{
90 Banfield 1982: 211.

91 Banfield 1991: 27.

92 Banfield 1982: 116.

93 Ibid. 178-179.

94 Ibid. 250.

95 See ibid. 171-179 et passim. I pointed out in Patron 2009: 222-226 that the attribution of certain first-person fictional narratives as skaz-narratives using Banfield's criteria was relatively problematic.

96 Banfield 1991: 28.
} 
by antithesis, be termed "monophony" appears in all recent discussions of the notion of voice, whatever the theoretical allegiances of the participants. Marc Blanchard criticizes the "reverence to an individual subject who remains unitary and whole" 97 in Genettian narratology. Andrew ", who quotes Blanchard abundantly, provides the following commentary on Genette's claim concerning narration which, in his view, is always in the first person: "The argument massively if somewhat abstractly consolidates the idea of person as a unifying, homogenizing, singular presence within a narrative text. Genette's case reverts to a theological conception of the text in which all separate narrative instances, including instances of voice, are governed by a single authoritative, 'higher' voice" 98 (Gibson on the contrary gives a lot of space to Banfield's theory). Aczel criticizes the narratological approach to voice as "a unified speaker position" and pleads for a notion of voice as "a composite configuration of quoted speech styles" "99; he then aims to show "how the essentially Bakhtinian notion of voice as composite and quotational [...] can provide a fruitful response to the critical anxieties of deconstruction concerning voice"100 (via deconstruction, Aczel is essentially targeting Gibson). Lastly, Korthals Altes, who refers back to both Gibson and Aczel, also concludes unsurprisingly that "[t]he attention for voice and its slipperiness should be part of the training in literary - and more general, cultural-competence, as the capacity to understand complex, polyphonic and dialogic language use, and how individuals and interpretive communities react to it". ${ }^{101}$

\section{Conclusion}

The phenomenon of homonymy has long been an object of concern for grammarians and logicians alike, who consider it a failure of languages particularly in technical languages such as those of science or philosophy. Homonymy and, incidentally, polysemy, are opposed to the ideal of a well-made language which would associate one form to one meaning; they lead to a penury of designations and thus generate confusion. Synonymy is not much better, as it introduces unnecessary redundancy and thus also runs counter to logical requirements. Homonymy between the different uses of the word "voice" for Genette, polysemy for Chatman and in a different way Banfield, multiple synonyms, an absence of strict antonyms:

97 Blanchard 1992: 64.

98 Gibson 1996: 145.

99 Aczel 2001: 598 (about Aczel 1998). See also ibid. 493-495.

100 Aczel 2001: 598.

101 Korthals Altes 2006: 191. 
all the data listed in this article should, I believe, lead to abandoning the notion of voice in narrative theory. Without any doubt, the possibility of non-contradictory discourse and full comprehension between theoreticians is founded on the univocal meaning of words and sentences.

Translated by Susan Nicholls

\section{References}

Aczel, Richard

1998 "Hearing Voices in Narrative Texts", New Literary History, 29.3, 467-500.

2001 "Understanding as Over-hearing: Towards a Dialogics of Voice", Voice and Human Experience, New Literary History 32.3, 597-617.

Bal, Mieke

2004 [1985] Narratology: Introduction to the Theory of Narrative, Toronto, Buffalo, London: University of Toronto Press.

Banfield, Ann

1973 "Narrative Style and the Grammar of Direct and Indirect Speech", Foundations of Language 10, 1-39.

1982 Unspeakable Sentences: Narration and Representation in the Language of Fiction, Boston and London: Routledge and Kegan Paul.

1985 "Ecriture, Narration and the Grammar of French", in: Narrative: From Malory to Motion Pictures, Stratford-Upon-Avon Studies, Second Series, edited by Jeremy Hawthorn, London: Edward Arnold, 1-24.

1991 "L'écriture et le non-dit", Diacritics 21.4, 21-31.

2003 [1992] "Literary Pragmatics, in: The International Encyclopedia of Linguistics, vol. 2, edited by William Bright, New York and Oxford: Oxford UP, 475-480.

Barthes, Roland

1973 [1966] "Introduction to the Structural Analysis of Narratives", in: Text: Essays Selected and Translated by Stephen Heath, New York: Hill \& Wang, 79-124; also at http://phoenixandturtle.net/excerptmill/barthes3.htm.

Benveniste, Émile

1971 [1959, 1966] "The Correlations of Tense in the French Verb", in: Problems in General Linguistics, translated by Mary E. Meek, Coral Gables: Miami University Press, 205215.

Blanchard, Marc

1992 "His Master's Voice", in After Genette: Current Directions in Narrative Analysis, edited by Carl R. Kropf and R. Barton Palmer, Studies in the Literary Imagination 25.1, 61-78.

Brenkman, John

2000 "On Voice", Novel: A Forum on Fiction 33.3, 281-306.

Chatman, Seymour

1980 [1978] Story and Discourse: Narrative Structure in Fiction and Film, Ithaca and London: Cornell University Press; reprint Cornell Paperbacks.

Fludernik, Monika

1993 The Fictions of Language and the Languages of Fiction: The Linguistic Representation of Speech and Consciousness, London and New York: Routledge.

2001 "New Wine in Old Bottles? Voice, Focalization, and New Writing", Voice and Human Experience, New Literary History 32.3, 619-638. 
Genette, Gérard

1982 [1966] "Frontiers of Narrative", in Figures of Literary Discourse, translated by Alan Sheridan, New York: Columbia University Press, 127-143.

1983 [1972, 1980] Narrative Discourse: An Essay in Method, translated by Jane E. Lewin, reprint Ithaca: Cornell UP, Cornell Paperbacks.

2007 [1983] Nouveau discours du récit, Paris: Le Seuil, reprint "Points".

1988 [1983] Narrative Discourse Revisited, translated by Jane E. Lewin, Ithaca: Cornell UP, Cornell Paperbacks.

Gibson, Andrew

1996 Towards a Postmodern Theory of Narrative, Edinburgh: Edinburgh University Press; "Postmodern Theory".

Hamburger, Käte

1993 [1957/1968] The Logic of Literature, translated by Marilynn J. Rose, Bloomington and Indianapolis: Indiana University Press.

Korthals Altes, Liesbeth

2006 "Voice, Irony and Ethos: the Paradoxical Elusiveness of Michel Houellebecq's Polemic Writing in Les particules élémentaires", in: Stimme(n) im Text: Narratologische Positionsbestimmungen, edited by Andreas Blödorn, Daniela Langer and Michael Scheffel, Berlin and New York: Walter de Gruyter, "Narratologia", 165-193.

Kuroda, S.-Y.

1979a [1973] "Where Epistemology, Style and Grammar Meet: A Case Study from Japanese", in: The (W)hole of the Doughnut: Syntax and its Boundaries, Ghent: E. Story-Scientia, "Studies in Generative Linguistic Analysis", 187-203.

1979b [1975, 1976] "Reflections on the Foundations of Narrative Theory-from a Linguistic Point of View", in: The (W)hole of the Doughnut: Syntax and its Boundaries, Ghent: E. Story-Scientia, "Studies in Generative Linguistic Analysis", 205-231.

1979c "Some Thoughts on the Foundations of the Theory of Language Use", Linguistics and Philosophy 3.1, 1-17.

Milner, Jean-Claude

1995 [1989] Introduction à une science du langage, Paris: Le Seuil, "Points".

Nielsen, Henrik Skov

2004 "The Impersonal Voice in First-Person Narrative Fiction", Narrative 12.2, 133-150.

Patron, Sylvie

2009 Le Narrateur: Introduction à la théorie narrative, Paris: Armand Colin, "U".

2011 "Homonymie chez Genette: l'opposition entre histoire et discours dans les théories communicationnelles et non communicationnelles du récit", in : Relire Benveniste: Actualité des recherches sur l'énonciation, edited by Émilie Brunet and Rudolf Mahrer, Louvain-la-Neuve: Academia-Bruylant (forthcoming).

Philippe, Gilles

2005 "Le style est-il une catégorie énonciative ?", in: De la langue au style, edited by JeanMichel Gouvard, Lyon: Presses universitaires de Lyon, 145-156.

Prince, Gerald

1982 Narratology: The Form and Functioning of Narrative, Berlin, New York, Amsterdam: Mouton Publishers, "Janua Linguarum. Series Maior".

Rimmon-Kenan, Shlomith

2002 [1983] Narrative Fiction: Contemporay Poetics, London and New York: Routledge.

1989 "How the Model Neglects the Medium: Linguistics, Language, and the Crisis of Narratology", The Journal of Narrative Technique 19.1, 157-166.

Ryan, Marie-Laure

1981 "When 'je' is 'un autre': Fiction, Quotation, and the Performative Analysis", Poetics Today 2.2, 127-155.

Schaeffer, Jean-Marie 
1999 [1995] "Temps, mode et voix dans le récit", in: Nouvean dictionnaire encyclopédique des sciences du langage, edited by Oswald Ducrot and Jean-Marie Schaeffer, Paris: Le Seuil, "Points", 710-727.

Scott Fitzgerald, Francis

1991 [1925] The Great Gatsby, Cambridge: Cambridge UP.

Shen, Dan

2001 "Narrative, Reality, and Narrator as Construct: Reflections on Genette's Narrating", Narrative 9.2, 123-129.

Soelberg, Nils

1984 “La narratologie: pour quoi faire?”, Revue romane 19.1, 117-129.

Stanzel, Franz K.

1984 [1979, 1982] A Theory of Narrative, translated by Charlotte Goedsche, Cambridge: Cambridge UP.

Woolf, Virginia

1996 [1925] Mrs Dalloway, London: Penguin Popular Classics. 